\title{
The Influence of Educational Background, Years of Service and Training on the Performance of Early Childhood Education Teachers
}

\author{
Darsinah*, Purwatiningsih \\ Department of Early Childhood Teacher Education, Universitas Muhammadiyah Surakarta, Indonesia
}

Received June 11, 2020; Revised August 17, 2020; Accepted August 28, 2020

\begin{abstract}
Cite This Paper in the following Citation Styles
(a): [1] Darsinah, Purwatiningsih, "The Influence of Educational Background, Years of Service, and Training on the Performance of Early Childhood Education Teachers," Universal Journal of Educational Research, Vol. 8, No. 10, pp. 4490-4497, 2020. DOI: 10.13189/ujer.2020.081016.
\end{abstract}

(b): Darsinah, Purwatiningsih (2020). The Influence of Educational Background, Years of Service, and Training on the Performance of Early Childhood Education Teachers. Universal Journal of Educational Research, 8(10), 4490-4497. DOI: 10.13189/ujer.2020.081016.

Copyright $\mathrm{C} 2020$ by authors, all rights reserved. Authors agree that this article remains permanently open access under the terms of the Creative Commons Attribution License 4.0 International License

\begin{abstract}
This study aims to determine (1) the influence of educational background, years of service and training on the performance of Early Childhood Education (ECE) teachers, (2) the effective contributions of educational background, years of service, and training to the performance of ECE teachers, and (3) the relative contributions of educational background, years of service, and training to the performance of ECE teachers. This research belongs to a quantitative correlational study. The study population involved all ECE teachers in Banyudono District, Boyolali Regency, Indonesia. Samples were taken by random sampling. Data on the educational background, years of service and training of the teachers were collected through documents. Teacher performance data were obtained using a questionnaire. The data analysis technique utilized a multiple linear regression. The study revealed the following findings: (1) simultaneously there was a significant influence between educational background, years of service, and training on the performance of ECE teachers, but partially the educational background had no influence on the teacher performance, (2) the effective contributions to teacher performance were $3.35 \%$ from the educational background, $18.73 \%$ from years of service, and $19.79 \%$ from training and (3) the relative contributions to the performance of teachers were $6.82 \%$ from the educational background, $48.18 \%$ from years of service and $43.19 \%$ from training.
\end{abstract}

Keywords Education, Years of Service, Training,
Performance

\section{Introduction}

Early Childhood Education (ECE) occupies an essential position in the education system, making it placed as an educational foundation. As a foundation for education, ECE supports education at the top level. In other words, the robustness of education at the top-level depends on the strength of the foundation supporting it. However, it will be realized if all components of ECE learning are in proper condition. Undoubtedly, the main component that really determines the quality of ECE is the teacher. The absence of qualified teachers causes the vital position of ECE difficult to realize, no matter how good the educational facilities and infrastructure are.

Being the 'second teacher' for children, an ECE teacher is considered way more influential for the children than the parents. In general, children are likely to be more obedient to teachers than to parents. If teachers make mistakes within education, it is hard for parents to correct the children. In consequence, teachers should carry on an excellent performance. Damim (2002) reveals that one of the characteristics of the educational crisis in Indonesia is the inability of teachers to demonstrate adequate work performance. 
Excellent performance requires an excellent educational background. The relevance of educational background will provide a strong scientific basis for work. Nevertheless, it needs to be supported with sufficient work period. The dynamic development of the environment requires teachers to balance and meet the demands of the development not to be left behind. One effort to overcome inequality is through training. Training is a short-term education to renew knowledge, provide additional knowledge, and improve practical skills for a particular purpose.

The problem that occurs in ECE is the poor ratio of teachers to children. Moreover, not all ECE teachers have an undergraduate degree. It can be seen from 2019-2020 ECE teacher statistics which state that there is 109,506 teachers ungraduated and 247,273 teachers have minimum bachelor degree with 13,219 ECE classes (Kemdikbud, 2020). Meanwhile in Indonesian Education Standards it is stated that the academic qualification of ECE teachers are Diploma IV or Bachelor of Early Childhood from accredited programs (Kemdikbud, 2014). Thus, the ratio of formal ECE teachers to children is 1: 27. While in ECE standards it is stated that the ratio of formal ECE teacher to children is 1:15. This condition has raised questions about the performance of ECE teacher in relation to their educational background, education and training.

Karwati \& Prinsa (2013) define performance as achievement, results, and demonstration of works. Referring to the Indonesian Law No. 14 of 2005 concerning teachers and lecturers, the main tasks of teachers are to educate, teach, guide, direct, train, assess, and evaluate students of ECE in the formal, basic, and secondary education. The formal education of ECE refers to kindergarten (a) place of learning for children aged 4-6 years), Roudhotul Athfal (a) place of learning for children aged 4-6 years), as well as other equivalent units. ECE teachers are those teaching in these institutions. Indeed, work performance requires qualified abilities.

The aspects of ECE teacher performance have been summarized by Lambert, Rowland, Wheeler, Ulrich, \& Bird (2008) by relying on the primary function. Five main functions must be assessed in ECE teacher, namely (1) facilitation development, (2) learning environment, (3) child self-regulation, (4) assessment and (5) relationship. Whereas the aspects of the teacher performance assessment instrument (TPAI), as mentioned Darsinah (2012), consist of (1) teaching plans and materials or called as lesson plans (LP), (2) Learning implementation (classroom procedure) and (3) personality (including interpersonal relationships). Interpersonal relationships can be integrated during the learning process. In carrying out learning, the teacher also collects data as material for evaluation. Evaluation of early childhood is performed after obtaining sufficient data. Therefore, performance appraisal is based on the ability of teachers in (1) making lesson plans, (2) carrying out learning and (3) evaluating learning.

There are three types of lesson plans in the Indonesian
Early Childhood Directorate (Direktorat Pembinaan Pendidikan Anak Usia Dini, 2015), the semester learning plan, the weekly lesson plan and the daily lesson plan. Early Childhood learning is conducted through stimulation, not instruction. It is based on the definition of Early Childhood Education stated in the Indonesian Law No. 20 of 2003 concerning ECE, article 1 chapter 1 verse 14, which reads, "ECE is a coaching effort aimed at children from birth until the age of six carried out through the provision of educational stimuli to help physical and spiritual growth and development that children have the readiness to enter further education." The existence of educational stimuli has had consequences for the nature of indirect learning, providing children the opportunity to construct their knowledge.

The implementation of Early Childhood learning is adapted to the world of children called the world of play. Therefore, Early Childhood learning is performed through play. Play is a free and enjoyable activity. Rubbin, Fien, \& Vandenberg in Rogers, Cosby, and Sawyer (1998) have proposed the activities belonging to the characteristic of play as follows: (1) Play is intrinsically motivated, (2) Play is relatively free of eternally imposed rules, (3) Play is carried out as if the activity were real, (4) Play focuses on the process rather than any product, (5) Play is dominated by the players, and (6) Play requires the active involvement of the player. The consequence of this theory in learning is the prohibition on giving instructions to children, either verbally or in writing, as in children's worksheets.

The evaluation in ECE is carried out through an assessment. Mindes in Gullo (2005) states that, "...assessment is a process for gathering information to make decisions about young children." Whereas Gullo (2005) believes that "....assessment is a procedure used to determine the degree to which an individual child possesses a certain attribute." Assessment is the process of getting information to make decisions about children. The word process has implications for getting data carried out continuously. In the Early Learning Standards Task Force and Kindergarten Assessment Work Group (2005), it is stated that "Caregivers and or teachers are committed to compiling ongoing observation data for every child several times (at least three times) each year during his/her education." Therefore, the assessment is not based on one event in learning but requiring several times of emergence of the observed aspect to be able to perform it. Information obtained depends on aspects of the assessment, both aspects of child development (child development-based assessment) and children's play (play based assessment).

A study conducted by Akiri (2014) discovered that the working experience or years of service affected the career satisfaction of a teacher. Phelps (2013) states that "A person needs one year to be comfortable and good at work." It indicates that despite having a sufficient scientific basis, a person should also be supported by sufficient work experience. The results of brain research conveyed by 
Phelps (2013) stated that "Experience is the architect of the brain." The brain, which is the nerve center controlling human activity, is designed by experience. For this reason, experience is vital in supporting teacher performance. The longer the work period, the more work experience a person has. Hence, it is assumed that the longer the working period, the better the performance.

A good performance generates an excellent teacher. Concerning the characteristics of an excellent teacher, Phelps (2013) mentions: "The caregiver or teacher must be willing to participate in workshops, meetings and other training, which will advance her knowledge of early childhood development. The knowledge of how young children grow and develop is regularly changing and improving our ability to support the children in our care." Thus, to be well-performed teachers, they should participate in training related to early childhood.

Sustainable development of teachers' competencies has received attention from the government. In the Indonesian Ministry Regulation of State Apparatuses Empowerment and Bureaucratic Reform (Kemenpanrb, 2009) regarding teacher's functional position and credit score in article 1 paragraph 5, it is stated that "Sustainable professionalism development is the development of teachers' competencies carried out following the needs, gradually, continuously to improve their professionalism." Sustainable professionalism development consists of three components, (1) self-development, (2) scientific publications and (3) innovative works. Functional training is one of the activities of self-development carried out to achieve competency requirements in accordance with the position. Therefore, the material always supports the competencies that must be achieved. Such training is therefore expected to support the performance of ECE teacher.

Research on the effects of educational background, years of service, and training on teacher performance has been conducted by several researchers. (1) Zuzovsky (2003) examined teacher qualifications and their impact on student achievement, (2) Saracho \& Spodek (2007) studied the early childhood teacher preparation, and quality of program results, (3) Leak (2012) investigated the influence of educational background, and teacher experience on student achievement, (4) Hart (1994) explored the integrating between years of service, psychology, and morals, (5) Ali \& Hamza (2018) researched the impact of teacher training on learning attitudes and organizations of students and the study of (6) Hervie \& Winful (2018) focused on improving teacher performance through training and development in education services.

Despite these past studies, not many of them focused on educational background, years of service, and training of ECE teachers, especially the correlation. That fact left a gap for more studies to do in Indonesia. Based on the problem statement above, the purposes of this study are; (1) to determine the influence of educational background, years of service, and training, on the performance of ECE teachers, (2) to determine the effective contributions of educational background, years of service, and training to the performance of ECE teachers and (3) to determine the relative contributions of educational background, years of service and training to the performance of ECE teacher.

\section{Materials and Methods}

This research was conducted on all ECE teachers in Banyudono District, Boyolali, Indonesia, in 2020, deriving from 13 ECE institutions with 57 teachers. Using a random sampling technique, the sample comprising 46 teachers was collected.

This research is a quantitative correlational study examining the relationships between variables of performance, educational background, years of service and training in ECE teachers. To achieve the research objective, measurements were carried out, which then the measurement results were processed using statistics to test the hypothesis.

Data collection was carried out using two instruments, a questionnaire and documentation. Performance data were collected using a questionnaire, while data on educational background, years of service and training were obtained using the documentation method. The performance questionnaire was developed from three components of teacher performance, namely the lesson plans making, learning implementation and learning evaluation. Each component was developed into statement items. There were 56 items in total consisting of 18 planning items, 23 implementation items and 15 evaluation items. The validity test of items in the instrument was carried out using the Pearson Product Moment Correlation [13], while the reliability test utilized the Cronbach Alpha $(\alpha)$ [14].

Before analyzing the data, prerequisite tests consisting of a normality test and a linearity test were performed. The normality test employed the Kolmogorov-Smirnov test, while the linearity test utilized the F-test. Data analysis techniques in the hypothesis test involved multiple linear regression analysis, simultaneous test, individual test and both relative and effective contributions. In multiple linear regression analysis, the simultaneous test used the F-test, the individual test utilized the T-test, and relative contributions (RC) and effective contributions (EC).

\section{Results}

\section{The Description of Data}

Data on the teachers' educational background showed 22 teachers graduating from high school, 7 teachers having a three-year Diploma's degree, and 17 teachers with a Bachelor's degree. Data on years of service could be classified into four, (a) 14 people having less than 5 years of a working period, (b) 25 people with 5-10 years of a working period, (c) 4 people with 10-15 years of a working 
period and (d) 3 people having a working period of more than 15 years. Data on the training that ECE teacher participated in comprised four groups, (a) 9 teachers had never participated in any training, (b) 27 teachers had attended training twice, (c) 4 teachers had attended training four times and (d) 6 teachers had attended training more than five times. The maximum score obtained from the performance data was 207 from the ideal maximum score of 224 and the minimum score of 132 was from the ideal minimum score of 56 .

\section{Normality Test}

The normality test was carried out using the Kolmogorov-Smirnov test. The results showed a coefficient value of 1.469 and a significance value of 0.077 , indicating that the significance value was $>0.05$. In a nutshell, the data were normally distributed.

\section{Linearity Test}

The results of the linearity test between the educational background and teacher performance were F-count $=2.065$, $\mathrm{F}$-table $=3.23$. Thus, F-count $=2.065<\mathrm{F}$-table $=3.23$ at sig. of $0.158>0.05$. In short, the relationship between the educational background and ECE teacher performance was linear. For the variables of years of service and teacher performance, the results were $\mathrm{F}$-count $=0.228$, and $\mathrm{F}$-table $=3.23$. Having F-count $=0.228<\mathrm{F}$-table $=3.23$, and the sig. value of $0.797>0.05$ indicated that the relationship between these two variables was linear.

\section{Multiple Linear Regression Test}

The equation of the multiple linear regression test from the SPSS output is presented in Table 1, showing constant results, and $\mathrm{X} 1, \mathrm{X} 2$, and $\mathrm{X} 3$, respectively, are educational background, years of service and training.

The equation means that (1) each addition of a one-unit value of the teacher's educational background variable (with an assumption that the variables of years of service and training are 0) will result in an increase in teacher performance by 4.311 units. (2) Every addition of a one-unit value of years of service (with an assumption that other variables are 0 ) will result in an increase in teacher performance by 8.022 units. (3) Each addition of a one-unit value of the training variable (with an assumption that the variables of educational background and years of service are 0) will result in an increase in teacher performance by 6.080 units. Based on the regression equation, it is seen that years of service contributed the most.

\section{Simultaneous Test}

Simultaneous test results are presented in Table 2. It depicts that the F-count value was 8.908, with a significance value of 0.000 , showing that $0.003<0.05$. Therefore, it can be concluded that simultaneously there was a significant effect between variables of educational background, years of service and training on the performance of ECE teacher.

Table 1. Multiple Linear Regression Test

Coefficients a

\begin{tabular}{|c|c|c|c|c|c|c|}
\hline & \multirow{2}{*}{ Model } & \multicolumn{2}{|c|}{ Unstandardized Coefficients } & \multirow{2}{*}{$\begin{array}{c}\text { Standardized } \\
\text { Coefficients } \\
\text { Beta }\end{array}$} & \multirow{2}{*}{$\mathrm{T}$} & \multirow{2}{*}{ Sig. } \\
\hline & & B & Std. Error & & & \\
\hline \multirow{4}{*}{1} & (Constant) & 136.667 & 9.689 & & 14.105 & 0.000 \\
\hline & Educational Background & 4.311 & 2.394 & 0.234 & 1.801 & 0.079 \\
\hline & Years of Service & 8.022 & 3.267 & 0.382 & 2.456 & 0.018 \\
\hline & Training & 6.080 & 2.907 & 0.313 & 2.091 & 0.043 \\
\hline
\end{tabular}

a. Dependent Variable: The performance of ECE teachers 


\section{Individual Test}

After knowing the results of the simultaneous test, the individual test was performed to determine the effect of each independent variable consisting of educational background, years of service, and training on teacher performance.

The results of the individual test showed that the t-count value of the educational background variable was 1.801 , with a significance value of 0.079 , indicating the significance value of $>0.05$. In short, there was no individual effect of educational background on the performance of ECE teacher.

The analysis results of the years of service variable revealed a $\mathrm{t}$-value of 2.456 and a significance value of
0.018 . It is followed by the training variable with a t-value of 2.091 and a significance value of 0.043 . These results showed that the significance values of both years of service and training were $<0.05$. In conclusion, there was a partial effect of the years of service and training on the performance of ECE teacher.

The results of the coefficient of determination test (R-squared test) in Table 2 showed an R-squared value of $0.389(38.9 \%)$ and adjusted R-squared of $0.345(34.5 \%)$. Hence, it can be concluded that the magnitude of influence of educational background, years of service, and training was equal to $0.345(34.5 \%)$. It indicated that other factors influenced ECE teacher performance by $100 \%-34.5 \%$ or $65.5 \%$.

Table 2. Coefficient Test of $\mathrm{X}$ and $\mathrm{Y}$

\begin{tabular}{|c|c|c|c|c|c|c|}
\hline \multicolumn{7}{|c|}{ Summary Model } \\
\hline Model & $\mathrm{R}$ & R Square & \multicolumn{2}{|c|}{ Adjusted R Square } & \multicolumn{2}{|c|}{ Std. Error of the Estimate } \\
\hline 1 & $0.624^{\mathrm{a}}$ & 0.389 & \multicolumn{2}{|c|}{0.345} & \multicolumn{2}{|c|}{13.779} \\
\hline \multicolumn{7}{|c|}{ a. Predictors: (Constant), Training, Educational Background, Years of Service } \\
\hline \multicolumn{7}{|c|}{ ANOVA } \\
\hline & Model & Sum of Squares & Df & Mean Square & $\mathrm{F}$ & Sig. \\
\hline \multirow{3}{*}{1} & Regression & 5073.901 & 3 & 1691.300 & 8.908 & $0.000^{\mathrm{b}}$ \\
\hline & Residual & 7973.838 & 42 & 189.853 & & \\
\hline & Total & 13047.739 & 45 & & & \\
\hline
\end{tabular}

a. Dependent Variable: The performance of ECE teachers

b. Predictors: (Constant), Training, Educational Background, Years of Service

\begin{tabular}{|c|c|c|c|c|c|c|}
\hline \multicolumn{7}{|c|}{ Coefficients a } \\
\hline & \multirow{2}{*}{ Model } & \multicolumn{2}{|c|}{ Unstandardized Coefficients } & \multirow{2}{*}{$\begin{array}{c}\text { Standardized } \\
\text { Coefficients } \\
\text { Beta }\end{array}$} & \multirow{2}{*}{$\mathrm{T}$} & \multirow{2}{*}{ Sig. } \\
\hline & & B & Std. Error & & & \\
\hline \multirow{4}{*}{1} & (Constant) & 136.667 & 9.689 & & 14.105 & 0.000 \\
\hline & Educational Background & 4.311 & 2.394 & 0.234 & 1.801 & 0.079 \\
\hline & Years of Service & 8.022 & 3.267 & 0.382 & 2.456 & 0.018 \\
\hline & Training & 6.080 & 2.907 & 0.313 & 2.091 & 0.043 \\
\hline
\end{tabular}

a. Dependent Variable: The performance of ECETeachers 


\section{Effective and Relative Contributions}

The effective contribution (EC) of educational background to the performance of ECE teachers (ECX1) was 0.0335 or $3.35 \%$. The effective contribution of years of service to teacher performance (ECX2) was 0.1873 or $18.73 \%$. The effective contribution of training (ECX3) to teacher performance was 0.1679 or $16.79 \%$. Thus, the total value of effective contributions was 0.389 or $38.9 \%$. This value matched the R-squared value of $38.9 \%$.

Relative contributions (RCs) from the educational background, years of service, and training to the performance of ECE teacher in a sequence are as follows. First, the relative contribution of educational background (RCX1) to teacher performance was 0.0682 or $6.82 \%$. Second, the relative contribution of years of service (RCX2) to the performance of ECE teacher was 0.4818 or $48.18 \%$. Third, the relative contribution of training attended by teachers (RCX3) was 0.4319 or $43.19 \%$. The contribution of each variable both the effective contribution and the relative contribution can be seen in Table 3 .

Table 3. The Contribution of Variables $\mathrm{X} 1, \mathrm{X} 2$, and $\mathrm{X} 3$ to the Performance of Early Childhood Teachers (Y)

\begin{tabular}{cccc}
\hline No & Variables & SE \% & SR \% \\
\hline 1 & Educational Background & 3.35 & 6.82 \\
\hline 2 & Years of Service & 18.73 & 48.18 \\
\hline 3 & Training & 16.79 & 43.19 \\
\hline & Total & 38.87 & 99.99 \\
\hline
\end{tabular}

\section{Discussion}

\section{Educational Background had no influence on the Teacher Performance}

The results of the multiple linear regression test obtained a positive regression coefficient value of the educational background variable (b1). In a nutshell, if the educational background is improved, it will increase the value of ECE teacher performance. However, the results of the partial test indicated that there was no significant effect of educational background on teacher performance. The effective contribution, as well as the relative contribution of educational background to teacher performance, appeared to be the smallest. It was due to the educational background of ECE teacher, in which 29 or $63 \%$ of them either had only a three-year Diploma's degree or merely graduated from high school, while 17 or $37 \%$ of them possessed a Bachelor's degree. In other words, some of them have not met the requirements of being ECE teacher for having no relevant educational background. In short, the knowledge of ECE teacher was less relevant to their work.

The results of this study are similar to Zuzovsky's (2003) research, where two variables had the opposite (though not significant) influences in the two subject areas. The first was having an advanced degree, and the second was majoring in teaching. The two variables were positively related but not significant, with achievement in science. However, the results of this study contradict the study of Saracho \& Spodek (2007), discovering the importance of a bachelor's degree and educational standards for ECE teacher.

In reality, the requirements to become ECE teacher are not in accordance with those stipulated in the Indonesian National Education System Law, that ECE teacher must have a minimum education qualification of a four-year Diploma's degree or Bachelor's degree in the field of ECE or psychology obtained from accredited study programs. The length of time needed to complete the education qualification is expected to be able to strengthen the cognitive structure of ECE. A strong cognitive structure will influence the performance of ECE teacher.

\section{The Effect of Years of Service on Teacher Performance}

The multiple linear regression test obtained a positive value of the regression coefficient of the years of service variable (b2). Hence, if the working period is increased, the performance of ECE teacher value will increase as well. The results of the partial test indicated a significant effect of years of service on ECE teacher performance.

In essence, the longer they work, the more work experience they gain, assuming to make better performance. This finding is similar to the results of Leak's research in 2012 in which teaching experience in the classroom appeared to make a real difference in student achievement. The years of service also teaches teachers many things related to their work. Therefore, it is no exaggeration that there is this phrase "experience is the best teacher."

In addition to improving student achievement, teaching experience can also improve teacher morale. It is reinforced by the results of Hart (1994) depicting that positive experiences contributed to morals. Conversely, negative experiences contributed to psychological distress.

\section{The Influence of Training on Teacher Performance}

The results of the multiple linear regression test showed a positive regression coefficient value for the variable of training attended by ECE teacher (b3). In short, if the training is improved, the performance of ECE teacher value will certainly increase. Partial test results indicated a significant effect of training on teacher performance.

Similar results were also found by Ali \& Hamza (2018) that with the large amount of training that teachers participated in, student learning attitudes could be positively changed. As a result, it affected all organizational performance positively. Training helps teachers to adopt new teaching techniques and methods.

Training is a series of activities designed to improve work knowledge and skills. The purpose of training, in general, is to improve performance. The training provided 
is commonly based on needs. Thus, the contents are always relevant and up to date. Such is the case with Hervie \& Winful (2018) research showing that poor teacher performance was caused by lack of training, lack of teaching and learning materials, lack of incentives and motivation, and inappropriate supervision. One that is related to the poor performance of teachers is due to lack of frequency of training in positions.

\section{Conclusions}

The following conclusions were drawn from the results of the data analysis. (a) There was a simultaneous influence between educational background, years of service, and training on the performance of ECE teacher. However, partially, the educational background did not have a major effect on teacher performance, (b) The effective contributions to ECE teacher performance were 3.35\% from the educational background, $18.73 \%$ from years of service, and $16.79 \%$ from training, (c) The relative contributions to ECE teacher performance consisted of $6.82 \%$ of educational background, $48.18 \%$ of years of service, and $43.19 \%$ of training.

Based on these conclusions, the following suggestions are provided: (a) The recruitment of ECE teacher should pay attention to academic qualifications appropriate to the work field of ECE, (b) Making a teacher remain in her profession as a ECE teacher, because the more experienced a teacher, the better the performance. It can be performed by increasing their welfare, (c) Intensifying teacher involvement in in-service training or training in positions related to early childhood continuously following the demands of child developmentt.

This study has several limitations such as: (1) Conducted in a relatively narrow area (sub-district), (2) The respondent only from one major Indonesian early childhood teacher organization namely HIMECEI since there is another one such as IGTKI. The authors suggest for future researchers to select more diverse respondents and wider research area.

\section{Acknowledgments}

The authors would like to extend their sincere gratitude to Mr. Muhamad Taufik Hidayat for his feedback on the manuscript. They are also very thankful for all of the respondents in Banyudono, Boyolali.

\section{REFERENCES}

[1] Akiri, A.A. (2014). Teachers' Career Satisfaction and Students' Academic Performance in Delta Public Secondary
Schools. Journal of Educational and Social Research MCSER Publishing, 4 (1), 267-272. http://doi.org/10.5901/j esr.2014.v4n1p267

[2] Ali, R. K. \& Hamza, M.A. (2018). Impact of Teachers' Training on Students' Learning Attitude and Organizational Performance. The International Journal of Business \& Management, 6:10, 239-248. https://www.researchgate.net/ publication/329153414

[3] Budiyono. (2009). Statistika untuk Penelitian [Statistics for Research]. Surakarta: UNS Press.

[4] Danim, S. (2002). Inovasi Pendidikan dalam Upaya Peningkatan Profesionalisme Tenaga Kependidikan [Educational Innovation in Efforts to Increase the Professionalism of Education Personnel]. Bandung: Pustaka Setia.

[5] Darsinah. (2012). Disertasi: Panduan Instrumen Penilaian Kinerja Guru Taman Kanak Kanak. [Guide to Kindergarten Teacher Performance Assessment Instruments] Semarang: Univeristas Negeri Semarang.

[6] Direktorat Pembinaan Pendidikan Anak Usia Dini. (2015). Penyusunan Rencana Pelaksanaan Pembelajaran Pendidikan Anak Usia Dini [Preparation of Early Childhood Education Learning Implementation Plan]. Jakarta: Kemendikbud

[7] Early Learning Standards Task Force and Kindergarten Assessment Work Group (2005). Early Childhood Assessment for Children from Birth to Age 8 (Grade 3). Harrisburg, PA: Pennsylvania's Departments of Education and Public Welfare.

[8] Gullo, D. F. (2005). Understanding Assessment and Evaluation in Early Childhood Education. New York: Teacher College Press.

[9] Hart, P. M. (1994). Teacher quality of work life: Integrating work experiences, psychological distress and morale. Journal of Occupational and Organizational Psychology, 67, 109-1 32. https://doi.org/10.1111/j.2044-8325.1994.tb0055 $5 . \mathrm{x}$

[10] Hervie, D. M. \& Winful, E.C. (2018). Enhancing Teachers' Performance through Training and Development in Ghana Education Service (A Case Study of Ebenezer Senior High School), Journal of Human Resource Management, 6(1), 1-8. http://doi.org/10.11648/j.jhrm.20180601.11

[11] Karwati, E. \& Prinsa, D.J. (2013). Kinerja dan Profesionalisme Kepala Sekolah Membangun Sekolah yang Bermutu [Performance and Professionalism of School Principals Building Quality Schools]. Bandung: Penerbit Alfabeta.

[12] Kemdikbud. (2014). Peraturan Menteri Pendidikan dan Kebudayaan Republik Indonesia Nomor 137 Tahun 2014 tentang Standar Nasional Pendidikan Anak Usia Dini.

[13] Kemdikbud. (2020) Statistik Pendidikan Anak Usia Dini 2019/2020. Jakarta

[14] Kempanrb / Kementerian Pemberdayaan Aparatur Negara dan Reformasi Birokrasi. (2009). Peraturan Menteri Pemberdayaan Aparatur Negara dan Reformasi Birokrasi Nomor 16 Tahun 2009 tentang Jabatan Fungsional Guru dan Angka Kreditnya [Regulation of the Minister for 
Empowerment of State Apparatuses and Bureaucratic Reform No. 16/2009 concerning Teacher Functional Position and Credit Scores].

[15] Kothari, C.R. (2004). Research Methodology: Methods and Techniques. New Delhi: New Age International (P) Limited Publisher.

[16] Lambert, R., Rowland B., Wheeler C., Ullrich A., \& Bird J. (2008). PreK-K Teacher Performance Appraisal Instrument (PKKTPAI) Teacher Evaluation System: Evaluator's Guide. North Carolina: Center for Educational Measurement and Evaluation.

https://ceme.uncc.edu/sites/ceme.uncc.edu/files/media/pdfs/ rev_pkktpai_final_color_guide.pdf

[17] Leak, J. A. (2012). Effects of Teacher Educational Background and Experience on Student Achievement in the Early Grades. ProQuest LLC. 789 East Eisenhower Parkway https://search.proquest.com/docview/1024425324

[18] Narimawati, U., Sarwono, J., Munandar, D., \& Winanti, M B. (2020). Metode Penelitian dalam Implementasi Ragam Analisis [Research Methods in Implementing Various Analysis]. Yogyakarta: CV Andi Offset

[19] Phelps, P. \& Stannard, L. (2013). Modul Konferensi V ECE:
Infants and Toddlers. Jakarta: Sekolah Al Falah Jakarta: Unpublished.

[20] Phelps, P. \& Stannard, L. (2019). Materi Workshop: How To Be Excellent Teacher. Jakarta: Sekolah Al Falah Jakarta: Unpublished.

[21] Riadi, E. (2016). Statistika Penelitian: Analisis Manual dan IBM SPSS [Research Statistics: Manual Analysis and IBM SPSS]. Yogyakarta: CV Andi Offset.

[22] Rogers, Cosby. S., \& Sawyer, J. K. (1998). Play in The Lives of Children. Washington, DC: National Association for the education of Young Children.

[23] Saracho, O. N. \& Spodek, B. (2007) Early childhood teachers' preparation and the quality of program outcomes, Early Child Development and Care, 177:1,71-91, http://dx.doi.org/10.1080/03004430500317366

[24] Walpole, R. E. (1988). Pengantar Statistik [Introduction of Statistics]. Jakarta: Gramedia.

[25] Zuzovsky, R. (2003). Teacher Qualifications and Their Impact on Student Achievement Findings from TIMSS-2003 Data in Israel. Journal of School of Education, Science \& Technology Education Center, Tel Aviv, Israel. 